\title{
Benthic diatoms of a high Arctic fjord (Young Sound, NE Greenland): importance for ecosystem primary production
}

\author{
Ronnie N. Glud ${ }^{1, *}$, Michael Kühl ${ }^{1}$, Frank Wenzhöfer ${ }^{1,3}{ }^{,}$, Søren Rysgaard ${ }^{2}$ \\ ${ }^{1}$ Marine Biological Laboratory, Copenhagen University, Strandpromenaden 5, 3000 Helsingør, Denmark \\ ${ }^{2}$ Department of Marine Ecology, National Environmental Research Institute, Vejlsøvej 25, 8600 Silkeborg, Denmark \\ ${ }^{3}$ Max Planck Institute for Marine Microbiology, Celsiusstr. 1, 28359 Bremen, Germany
}

\begin{abstract}
Patches of benthic diatoms covered 23 to $73 \%$ of the sediment area at water depths down to $30 \mathrm{~m}$ of a high Arctic fjord system (Young Sound, NE Greenland). Mapping of the in situ chlorophyll (chl a) fluorescence by a pulse amplitude modulated (PAM) fluorometer demonstrated the presence of diatom-covered sediment patches with a characteristic size scale of 5 to $8 \mathrm{~m}$. The benthic diatoms were well adapted to the ambient irradiance as demonstrated by in situ measurements of the relative electron transport rate (ETR) versus irradiance. However, the characteristics of the PE (photosynthesis versus downwelling irradiance) relations changed within minutes after exposure to changed light conditions neutralizing any depth related light acclimation. This demonstrated that the diatoms efficiently optimized their photosynthetic apparatus to the current light conditions. Steady state $\mathrm{O}_{2}$ microprofiles measured in situ and in the laboratory showed a gradual increase in the $\mathrm{O}_{2}$ penetration depth and $\mathrm{O}_{2}$ concentration at the sediment surface with increasing irradiance. Net photosynthesis showed a compensation irradiance of $4.5 \mu \mathrm{mol}$ photons $\mathrm{m}^{-2} \mathrm{~s}^{-1}$ and a net photosynthetic capacity $\left(\mathrm{P}_{\max }\right)$ of $85 \mathrm{O}_{2} \mathrm{mmol}$ $\mathrm{m}^{-2} \mathrm{~d}^{-1}$. No photoinhibition was observed at the maximum irradiance of $140 \mu \mathrm{mol}$ photons $\mathrm{m}^{-2} \mathrm{~s}^{-1}$. Total exchange rates of $\mathrm{O}_{2}$ and DIC mirrored each other and confirmed the depth distribution of benthic diatoms and the microsensors measurements. The compensation irradiance for the integrated benthic community (including macrofauna) decreased with water depth to a minimum of $12 \mu \mathrm{mol}$ photons $\mathrm{m}^{-2}$ $\mathrm{s}^{-1}$ at $30 \mathrm{~m}$ water depth. The mean $\mathrm{O}_{2} /$ DIC exchange ratio across the benthic interface was approximately 1.2 and was independent of water depth. Extrapolation of our productivity data to the outer fjord system by accounting for the in situ light regime showed that the primary production of the benthic diatoms was equivalent to that of benthic macroalgae. Benthic net photosynthesis was almost 7 times higher than the gross photosynthetic rates of the pelagic community for water depths $<30 \mathrm{~m}$. However, integrated for the entire outer Young Sound, benthic net photosynthesis only accounted for $\sim 70 \%$ of the pelagic production as measured by the ${ }^{14} \mathrm{C}$-incubation technique.
\end{abstract}

KEY WORDS: Benthic microphytes $\cdot$ Microelectrodes $\cdot$ Photosynthesis

\section{INTRODUCTION}

Sediment sampling and photo-documentation of the high Arctic shelf have revealed high macrofauna abundance and biomass (e.g. Grebmeier \& McRoy

*E-mail: rnglud@zi.ku.dk
1989, Piepenburg et al. 1995, Sejr et al. 2000). Additionally, several investigations have demonstrated that the benthic microbial activity in these permanently cold waters is significant and typically matches activities found in similar settings at lower latitudes (e.g. Grebmeier et al. 1988, Hulth et al. 1994, Glud et al. 1998, Rysgaard et al. 1998, Kostka 1999). The benthic activity is driven by the primary production of either 
phytoplankton, ice algae, benthic macro- or microalgae. The annual primary production of phytoplankton in the Arctic is surprisingly high despite periods with ice cover and low irradiance during winter (Sambrotto et al. 1984, Subbarao \& Platt 1984). In some areas, a significant contribution to primary production is due to ice algal communities (e.g. Horner \& Schrader 1982, Hsiao 1988, Cota et al. 1991).

Benthic microphytes can contribute significantly to ecosystem primary production of temperate and tropical shallow water habitats (e.g. Grøntved 1962, Colijn \& de Jonge 1984, Cahoon \& Cooke 1992), and benthic diatoms can present a primary food source for estuarine food webs (e.g. Peterson \& Howarth 1987, Sullivan $\&$ Moncreiff 1990, Middelburg et al. 2000). The importance of benthic microalgae for ecosystem primary production on a global scale was underlined by a recent compilation based on 85 worldwide studies (Cahoon 1999). However, most of these studies were performed in intertidal areas and only 4 studies were performed in polar regions. The shelf area of the Arctic oceans is enormous, accounting for $\sim 22 \%$ of the global shelf area (depths <200 m) (Menard \& Smith 1966). The importance of benthic microalgae for ecosystem primary production in the Arctic is an area that has not been thoroughly explored.

A detailed investigation of the $\mathrm{C}$ cycling in a high Arctic fjord system, Young Sound (NE Greenland), showed that the primary production of phytoplankton and ice algae could not account for the $C$ input required by the benthic community (Rysgaard et al. 1998, 1999, 2001, Glud et al. 2000a). The aim of the present study was to quantify and evaluate the importance of benthic microalgae in primary production in the outer Young Sound; a site which is representative of numerous fjords along the eastcoast of Greeenland. Data are discussed in the context of previous production estimates and mineralization rates for the area and adds to the limited database on benthic primary production in the high Arctic.

\section{MATERIALS AND METHODS}

Study site, sampling and experimental set-up. The outer Young Sound, NE Greenland, covers an area of $132 \mathrm{~km}^{2}$ and has an average water depth of $65 \mathrm{~m}$ (Glud et al. 2000a). The Sound is ice covered for $\sim 9$ to $10 \mathrm{mo}$ of the year, but during the short summer $\sim 40 \%$ of the sea floor can potentially support benthic primary production, as evaluated from the distribution of coralline red algae, which mark the depth limits of primary production (Roberts et al. 2002). Our measuring campaign started on 30 July 2000, 19 d after the ice cover disappeared, and continued for approximately 1 mo.
Drifting ice remained in the Sound until early August before it was exported to the Greenland Sea. Ice cover re-appeared at the beginning of October and attained a thickness of $\sim 0.3 \mathrm{~m}$ after $1 \mathrm{mo}$. Five stations positioned along a linear transect off the Stn 'Daneborg' (Rysgaard et al. 1998, Glud et al. 2000a) were selected for our investigation of benthic microalgae (Fig. 1). Geographic positions and station characteristics are given in Table 1.

During the first days of the campaign, 7 sediment cores $(5.3 \mathrm{~cm}$ in diameter) were collected at each of the 5 stations. SCUBA divers sampled sediments at the shallow stations, while a modified 'Kajak-sampler' (KC-Denmark, Silkeborg) was used for retrieving sediment cores from the 2 deepest sites. Undisturbed, samples were placed in dark insulated boxes and brought back to the laboratory within $2 \mathrm{~h}$ of sampling. In the laboratory, the cores were placed in bottom water sampled at the respective sites and kept at $0^{\circ} \mathrm{C}$. A light:dark cycle of 18:6 h was established in order to mimic a diel cycle of irradiance. Despite the midnight sun, the decreasing inclination resulted in a very low in situ night irradiance at the respective water depths (see below). Two $120 \mathrm{~W}$ halogen lamps provided an incident irradiance around $25 \mu \mathrm{mol}$ photons $\mathrm{m}^{-2} \mathrm{~s}^{-1}$ at the sediment surface. The water bath was continuously aerated in order to maintain in situ air saturation. Two cores from each site were used to determine sediment porosity (0 to $0.5 \mathrm{~cm}$ ), as determined from the density and the water content measured as the weight loss after drying at $105^{\circ} \mathrm{C}$ for $24 \mathrm{~h}$ (Table 1 ).

Light measurements. To estimate the fraction of incident irradiance (PAR) that remained at the respective water depths, scalar irradiance profiles were measured in the water column of central Young Sound on a regular basis using a CTD unit (Datasonde, R4, Hydrolab), and these data were used for calculating light attenuation coefficients. No CTD data were recorded at the shallow sites. During most of the period the water column was characterized by an upper and lower horizon with a relatively high and low light extinction coefficient, respectively (Fig. 2A). The higher extinction coefficient in the upper water layers may have been due to: (1) higher levels of light absorbing material; and/or (2) selective removal of blue light by gelbstoff washed out from land (Kirk 1995). Additionally, at each of the 3 shallowest stations planar light loggers (HOBO) were positioned just above the water surface and at the bottom at the respective water depths. After inter-calibration to a planar underwater quantum sensor (LiCor, LI-192A), simultaneously recorded data were used to calculate the fraction of the downwelling irradiance that remained at the respective water depths. These measurements were performed frequently and on a regular basis during the measuring 
Table 1. Characteristics at the 5 investigated stations. nd $=$ not determined

\begin{tabular}{|c|c|c|c|c|c|c|}
\hline \multirow[t]{2}{*}{ Station } & \multirow{2}{*}{$\begin{array}{c}\text { Positions } \\
\text { (latitude, longitude) }\end{array}$} & \multirow{2}{*}{$\begin{array}{c}\text { Water } \\
\text { depth (m) }\end{array}$} & \multirow{2}{*}{$\begin{array}{l}\text { Tempera- } \\
\text { ture }\left({ }^{\circ} \mathrm{C}\right)\end{array}$} & \multirow{2}{*}{$\begin{array}{l}\text { Porosity }^{a} \\
(\mathrm{v} / \mathrm{v})\end{array}$} & \multicolumn{2}{|c|}{ Fraction of incident irradiance (\%) } \\
\hline & & & & & $\mathrm{HOBO}$ & CTD \\
\hline I & $74^{\circ} 18^{\prime} 59^{\prime \prime}, 20^{\circ} 14^{\prime} 09^{\prime \prime}$ & 5 & 2.2 & 0.50 & $12.2 \pm 4.6(\mathrm{n}=51)$ & $31.4 \pm 7.7(\mathrm{n}=9)$ \\
\hline II & $74^{\circ} 18^{\prime} 59^{\prime \prime}, 20^{\circ} 14^{\prime} 24^{\prime \prime}$ & 10 & 1.1 & 0.62 & $9.8 \pm 4.5(\mathrm{n}=130)$ & $11.1 \pm 5.0(\mathrm{n}=9)$ \\
\hline III & $74^{\circ} 18^{\prime} 58^{\prime \prime}, 20^{\circ} 14^{\prime} 48^{\prime \prime}$ & 20 & -0.5 & 0.78 & $3.2 \pm 1.3(\mathrm{n}=116)$ & $2.9 \pm 1.5(\mathrm{n}=9)$ \\
\hline IV & $74^{\circ} 18^{\prime} 59^{\prime \prime}, 20^{\circ} 14^{\prime} 74^{\prime \prime}$ & 30 & -1.3 & 0.80 & nd & $1.9 \pm 0.9(\mathrm{n}=7)$ \\
\hline V & $74^{\circ} 18^{\prime} 59^{\prime \prime}, 20^{\circ} 15^{\prime} 28^{\prime \prime}$ & 40 & -1.3 & 0.81 & nd & $0.4 \pm 0.6(n=9)$ \\
\hline
\end{tabular}

campaign. The fraction of downwelling irradiance remaining at the respective water depths derived by the 2 different approaches generally agreed reasonably well and the average values are presented in Table 1. Only for the $5 \mathrm{~m}$ station did estimates derived from water column profiles measured in the central Sound differ from measurements performed at the station itself. This is most likely associated to higher turbidity at the shallow water depth. For the calculations performed at the shallow stations (see below), we only used the HOBO-sensor derived data.

The incident downwelling irradiance (PAR) was measured nearby $(\sim 20 \mathrm{~km})$ hourly during 2000 by the Zackenberg Ecological Research Operations (Danish Polar Centre). Combined with information of the snow and ice cover, average extinction coefficients for ice and snow (Roberts et al. 2002), and the extinction coefficient for the water column, the seasonal irradiance
A

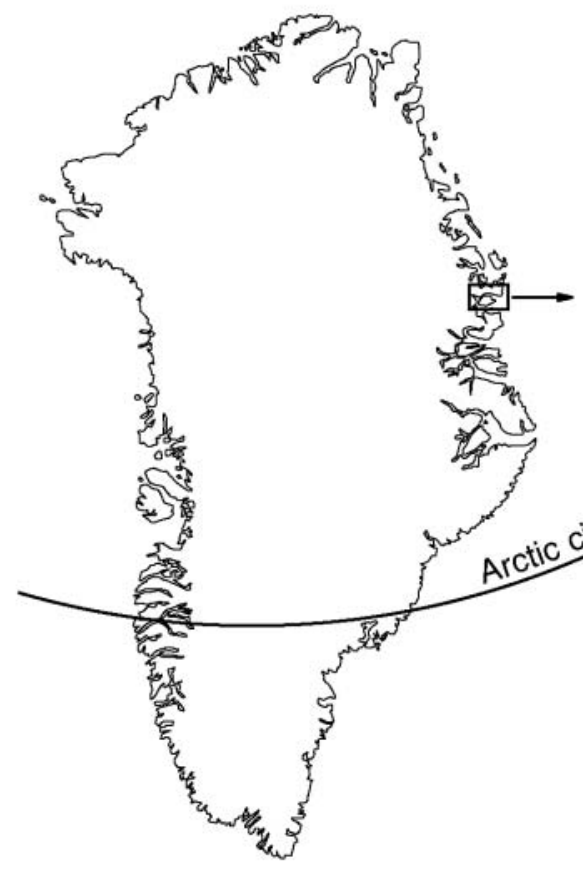

Fig. 1. Study site, Daneborg, NE Greenland. The gray zone in panel B represents the outer Young Sound as defined in this study and the seafloor topography is shown in panel $\mathrm{C}$. The thick line in panel $\mathrm{C}$ marks the positions of the investigated transect. Zero: Zackenberg Ecological Research Operations

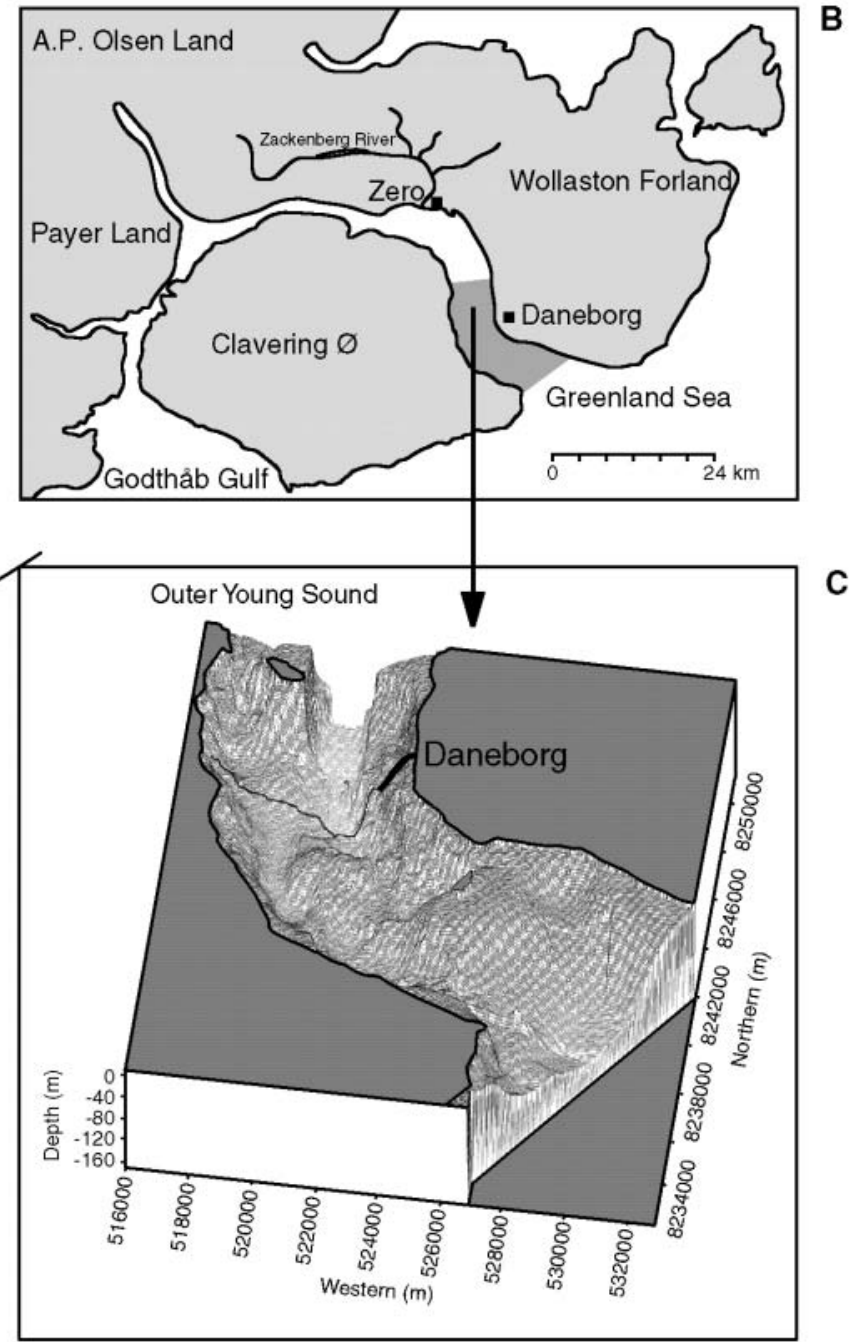


(PAR) at each depth of the respective stations could be estimated (Fig. 2B). It is apparent that very limited amounts of light reach the seafloor during ice cover.

Areal cover of benthic diatoms. Benthic diatoms were the predominant phototroph found on and within the upper layers of sediments. The in situ areal cover of benthic diatoms was determined from digital images. At the 3 shallowest stations, SCUBA divers used a hand-held digital camera (Sony DSC-P1) for obtaining a series of images depicting the sediment surface at randomly chosen sites. At the 2 deepest sites, a video camera (Sony VX-1000) mounted on a tripod was lowered from a rubber boat. The images covered an
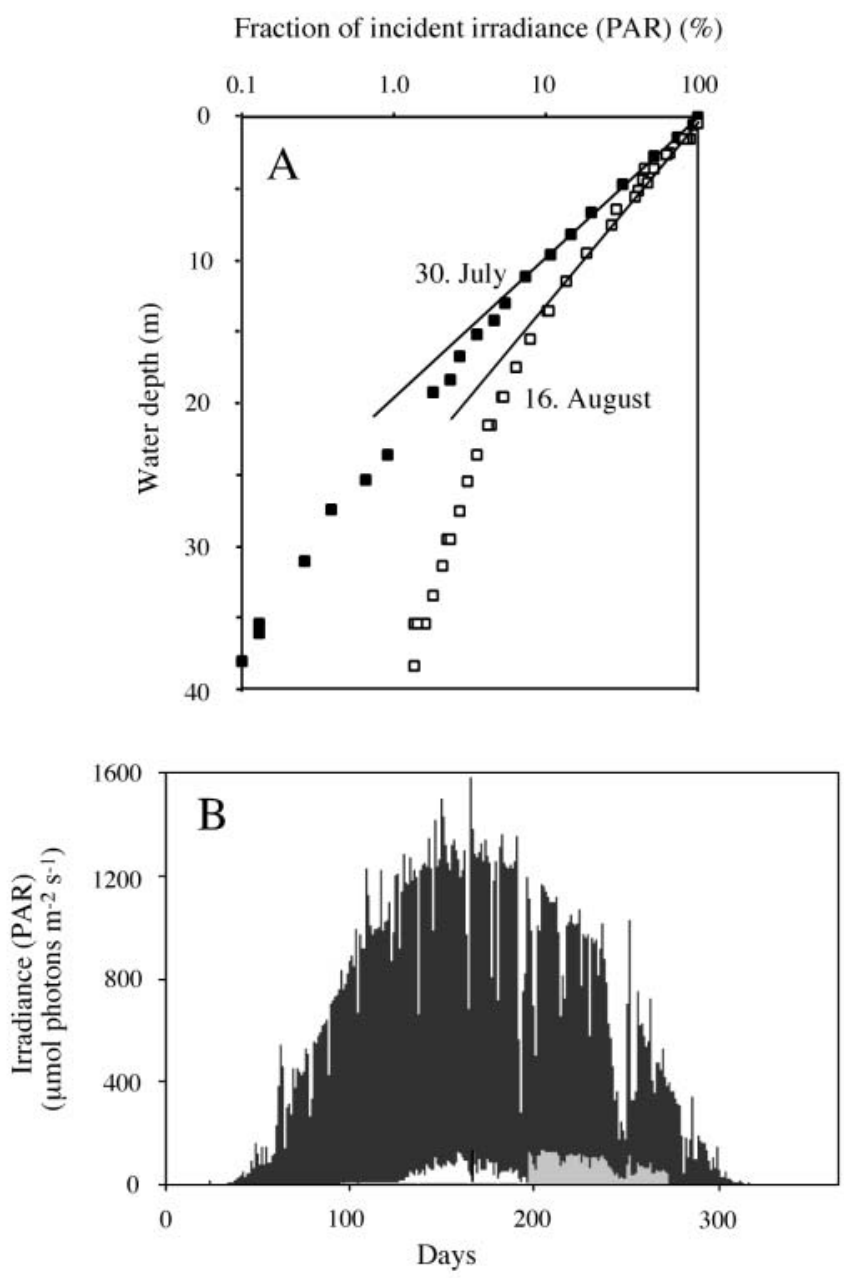

Fig. 2. (A) Vertical water column profiles of downwelling irradiance (PAR) measured in central Young Sound on 2 occasions. Data represent the extremes of the light profiles obtained during the study. (B) Downwelling irradiance (PAR) during a yearly cycle at Zackenberg. Dark columns represent maximum and minimum values on each day in air just above the water surface, while gray bars indicate calculated values at $10 \mathrm{~m}$ water depth accounting for ice cover and the extinction coefficient in the water column. The enclosed white area reflects the period with midnight sun, where PAR values never reached 0
Table 2. Dominant genera and areal average coverage of benthic diatoms (mean $\pm \mathrm{SD}$ )

\begin{tabular}{|llr|}
\hline Station & Dominant genera & Coverage $(\%)$ \\
\hline $5 \mathrm{~m}$ & Pinnularia, Nitzschia & $23 \pm 8(\mathrm{n}=19)$ \\
$10 \mathrm{~m}$ & Pinnularia, Nitzschia, Navicula & $26 \pm 14(\mathrm{n}=33)$ \\
$20 \mathrm{~m}$ & Pinnularia, Navicula & $73 \pm 16(\mathrm{n}=53)$ \\
$30 \mathrm{~m}$ & Pinnularia, Navicula & $36 \pm 11(\mathrm{n}=31)$ \\
$40 \mathrm{~m}$ & - & $0 \pm 0(\mathrm{n}=10)$ \\
\hline
\end{tabular}

approximate area of $1200 \mathrm{~cm}^{2}$. The areal fraction covered by a light to dark brown color was visually determined for each image (Fig. 3). Numerous diver obtained video recordings of the area confirmed the general depth related pattern in the benthic diatom cover shown in Table 2. Microscopic inspection of recovered sediment samples confirmed that the brownish color was caused by the presence of benthic diatoms. Samples of recovered surficial sediment were fixed in Lugol's solution for later identification of the dominating taxa of benthic microalgae. In all instances, benthic diatoms mainly of the genera Pinnularia, Nitzschia and Navicula were dominant (Table 2).

Pulse amplitude modulated measurements. The minimal chlorophyll (chl a) fluorescence yield, $F_{0}$, and the relative electron transport rate (ETR) between PSII and PSI was determined both in situ and in the laboratory with an underwater pulse amplitude modulated (PAM) fluorometer (Diving-PAM) by applying the socalled 'saturation pulse method'. By this approach, the sample is illuminated with weak modulated probing light for non-invasive monitoring of the fluorescence yield. For dark-adapted samples this results in a minimal fluorescence yield, $F_{0}$, which correlates well with the chl a content of microalgae and has been used as a proxy for the phototrophic biomass (Serodio et al. 1997, Barranguet \& Kromkamp 2000, Rysgaard et al. 2001, Glud et al. 2002). Exposing the sample to actinic light supplied by an internal halogen lamp results in an elevated fluorescent signal, $F$, and the subsequent exposure to a saturating light pulse $(0.6$ to $0.7 \mathrm{~s}$ at $\sim 5000 \mu \mathrm{mol}$ photons $\mathrm{m}^{-2} \mathrm{~s}^{-1}$ ) leads to the maximal fluorescent signal $F^{\prime}{ }_{m}$. Without additional pulsing, the fluorescence will gradually revert to the original $F$-value. The modulated probing light, the actinic light, the saturation pulse and the fluorescent signals were guided between instrument and sample by a $8 \mathrm{~mm}$ $(1.5 \mathrm{~m})$ fiber cable (Kühl et al. 2001). The irradiance of the actinic light at the different settings was measured by an underwater quantum irradiance sensor (LiCor LI-192SA). Ambient downwelling irradiance was measured by the irradiance sensor Diving-PAM, which was calibrated against the LiCor sensor. 
The relative ETR between PSII and PSI can be calculated as: $\left[\left(F_{\mathrm{m}}-F\right) / F_{\mathrm{m}}\right] \mathrm{E}_{0}(\mathrm{PAR})$, where $\mathrm{E}_{0}(\mathrm{PAR})$ is the intensity of the photosynthetic active radiance (Hofstraat et al. 1994). This simple approach assumes that the absorption cross-section of PSII $\left(\sigma_{a}\right)$ is constant during the measurements. This requirement is fulfilled during measurements of so-called rapid light curves (RLC), where actinic light only is exposed to the community for a short period (10 to $20 \mathrm{~s}$ ) (Schreiber et al. 1997, Ralph et al. 1999). Such measurements thereby provide a snap-shot of the photoacclimation of the microalgae to ambient conditions without interference from transient adaptation. In the present study, we used 9 gradually increasing levels of actinic light, which were exposed for durations of 10, 120 or $180 \mathrm{~s}$. The latter period is the maximal period of actinic light possible with the Diving-PAM. A more comprehensive description of the applied methodology is presented elsewhere (Kühl et al. 2001).

During measurements in the laboratory, the fiber-head was mounted 1 to $3 \mathrm{~mm}$ above the sediment surface, and $F_{0}$ and ETR measurements were performed in cores from all 5 stations. In situ measurements of ETR were only conducted by SCUBA diving at the 3 shallowest sites. It was impossible to perform in situ measurements on completely dark-adapted algae. Consequently no true $F_{0}$ values were obtained and only $F$-values at ambient, albeit low irradiance were measured in situ. To access the in situ spatial variability of the phototrophic biomass, F-values at 7 to $10 \mu \mathrm{mol}$ photons $\mathrm{m}^{-2} \mathrm{~s}^{-1}$ ambient irradiance were measured on different spatial scales. A total of 96 point measurements separated by 9 classes of distance from $2.5 \mathrm{~cm}$ to $1 \mathrm{~km}$ were obtained, along the $10 \mathrm{~m}$ isobath. For intercalibration between $F_{0}$ and the chl a concentrations within the upper sediment layers, both measurements were performed at the same spot in recovered sediment cores. After measuring $F_{0}$ at a given spot, subcores (8 $\mathrm{mm}$ in diameter) were obtained and the upper $3 \mathrm{~mm}$ were frozen. Concentrations of chl a were determined by a spectrophotometer after extraction in 96\% ethanol (Jespersen \& Christoffersen 1972).
$\mathrm{O}_{2}$ microprofiles. The microdistribution of $\mathrm{O}_{2}$ across the sediment-water interface was measured by Clark type microelectrodes equipped with an internal reference and a guard cathode (Revsbech 1989). The electrodes had tip diameters of $<2 \mu \mathrm{m}$, stirring sensitivities $<1 \%$ and a $90 \%$ response time $<1$ s (Revsbech 1989, Glud et al. 2000b). The sensors were positioned by a motor-driven micromanipulator and the sensor current was measured with a picoammeter connected to an
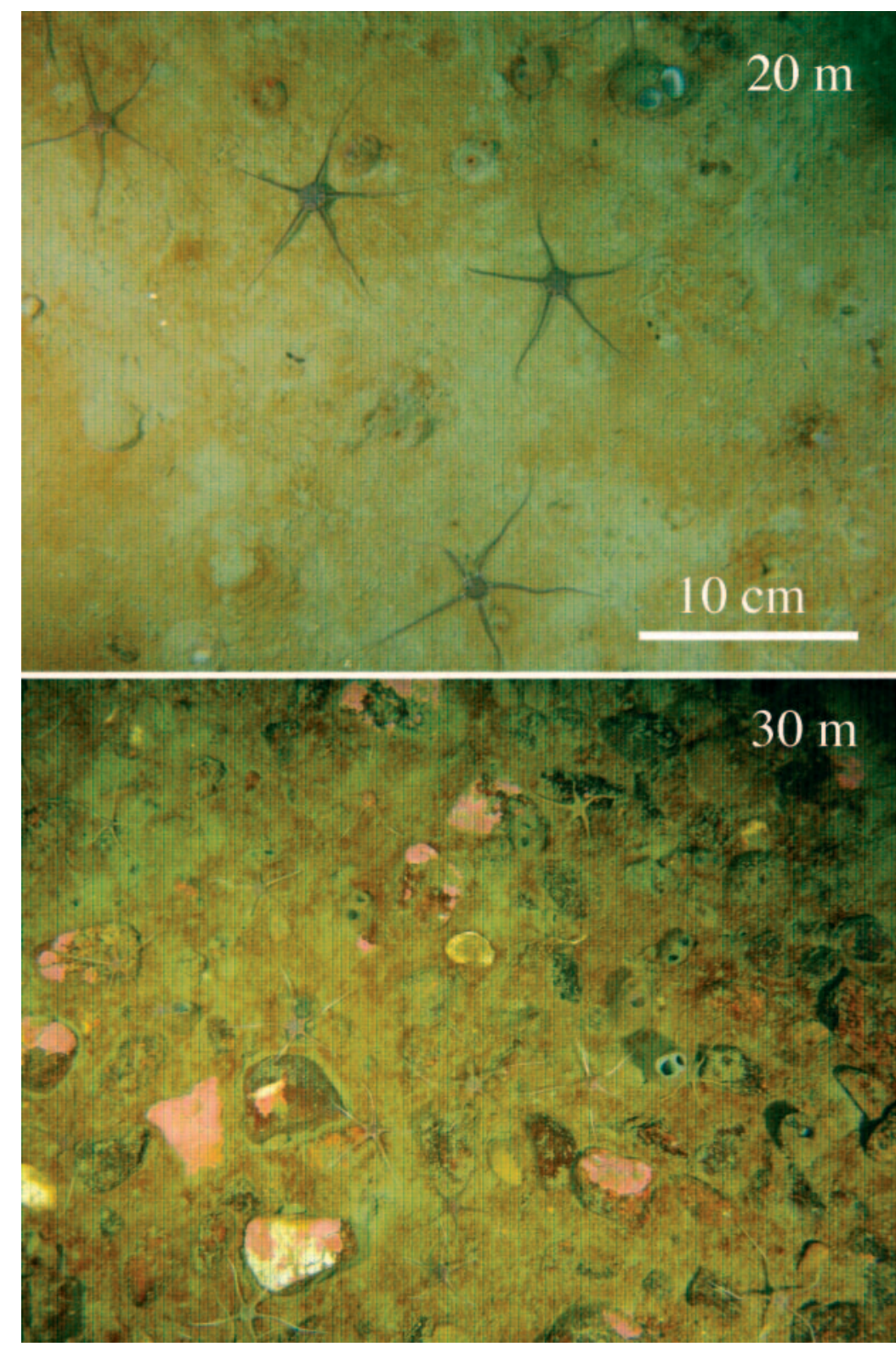

Fig. 3. Photographs of the seafloor in Young Sound obtained at the 20 and $30 \mathrm{~m}$ stations. An extensive brownish cover of benthic diatoms is apparent and their areal coverage was estimated to 85 and $45 \%$, respectively. The dominant macrofauna at the 2 stations were the brittlestars Ophiura robusta and Ophiocten sericeum, and the bivalves Mya truncata and Hiatella arctica. Crustose coralline red algae are seen at the $30 \mathrm{~m}$ site 
A/D converter that transferred the signals to a PC (Revsbech \& Jørgensen 1986). Profiles were measured with a depth resolution of $100 \mu \mathrm{m}$ and only at sites that was a covered by diatoms and unaffected by fauna.

For microprofiling in the laboratory, sediment cores were placed in a small water bath, kept at $0^{\circ} \mathrm{C}$. A fiber optic halogen lamp (Schott KL1500) equipped with a heat filter and a collimating lens was used as light source. Measurements were performed in darkness and at increasing irradiance until a maximum of $108 \mu \mathrm{mol}$ photons $\mathrm{m}^{-2} \mathrm{~s}^{-1}$ was reached. To ensure steady state, the $\mathrm{O}_{2}$ concentration within the photic zone was recorded continuously after changing the irradiance and profiling was only initiated after a constant signal was reached. During measurements rotating Teflon-coated magnets, attached to the inner wall of each coreliner, ensured a well-mixed overlying water phase (Rasmussen \& Jørgensen 1992).

$\mathrm{O}_{2}$ microprofiles were also measured in situ using a slightly modified and miniaturized version of the microprofiling instrument, PROFILUR (Gundersen \& Jørgensen 1990, Wenzhöfer et al. 2000). A SCUBA diver carefully placed the tripod at the sediment surface and after 15 to $30 \mathrm{~min}$ the microsensors were moved into the sediment in increments of $50 \mu \mathrm{m}$. At each deployment, the instrument was equipped with 3 to $6 \mathrm{O}_{2}$ microelectrodes, having the same measuring characteristics as outlined above. Due to drifting ice only a few deployments were successful.

The constant signals measured in the overlying water phase and in the anoxic sediment, respectively, served as inherent calibration points for the obtained microprofiles. From the calibrated microprofiles, the net photosynthesis (i.e. the $\mathrm{O}_{2}$ export from the photic zone), could be calculated as the sum of the diffusive flux towards the overlying water and the downward flux towards the heterotrophic or chemolithotrophic communities in the deeper sediment strata (Glud et al. 1992, Kühl et al. 1996). The upward flux was determined as

$$
J_{\text {up }}=-D_{0} \delta \mathrm{C}(z) / \delta z
$$

where $D_{0}$ is the molecular diffusion coefficient for $\mathrm{O}_{2}$ and $\mathrm{C}(z)$ is the $\mathrm{O}_{2}$ concentration at depth $z$ within the diffusive boundary layer (DBL) (Crank 1983). The molecular diffusion coefficient was from Broecker \& Peng (1974) and corrected for temperature as described by Li \& Gregory (1974). In a similar manner, the downward flux was calculated from

$$
J_{\text {down }}=-D_{\mathrm{s}} \delta \mathrm{C}(z) / \delta z
$$

where $\delta \mathrm{C}(z) / \delta z$ is the slope of the concentration profile just below the photic zone, defined as the inflection point of the concentration profile from net production to net consumption of $\mathrm{O}_{2}$ (Kühl et al. 1996). The sedi- ment diffusion coefficient $\left(D_{\mathrm{s}}\right)$ for $\mathrm{O}_{2}$ was derived from the molecular diffusion coefficient corrected for tortuosity by

$$
D_{\mathrm{s}}=D_{0} \phi^{2}
$$

where $\phi$ is the porosity (Ullmann \& Aller 1982).

Total incubations. The total exchange rate of $\mathrm{O}_{2}$ (TOE) and DIC was determined at 5 different irradiances for each of the recovered cores. The irradiance was changed by regulating the distance of the light source relative to the sediment surface, and cores were subsequently preincubated 2 to $4 \mathrm{~h}$ before exchange measurements were performed. Incubations were initiated by capping the submerged cores by a transparent lid. Rotating Teflon-coated magnets in the core-liner ensured a well-mixed overlying water phase above the sediment. Samples of the enclosed water volume were recovered initially and at the end of each incubation. Samples were transferred to $12 \mathrm{ml}$ gas tight vials. Samples were used for determination of the $\mathrm{O}_{2}$ concentration by Winkler titration (Strickland \& Parsons 1972), or preserved with $100 \mu \mathrm{l}$ saturated $\mathrm{HgCl}_{2}$ for later analysis of the DIC concentration on a coulometer (SM5012, UIC). The absolute change in $\mathrm{O}_{2}$ concentration never exceeded 30\% during the incubations, and a few cores were sampled 3 to 5 times during an incubation to confirm a linear concentration change over time. Total exchange rates were calculated from the observed concentration change accounting for the volume of the enclosed water. After incubations the sediment was sieved through a $500 \mu \mathrm{m}$ mesh screen and macrofauna were collected, identified and weighed. The dry weight of the macrofauna was determined after $24 \mathrm{~h}$ at $105^{\circ} \mathrm{C}$.

\section{RESULTS}

\section{Measurements of fluorescence parameters}

Rapid light curves (relative ETR vs irradiance) measured in situ at the $5 \mathrm{~m}$ station, showed no photoinhibition at an irradiance up to $212 \mu \mathrm{mol}$ photons $\mathrm{m}^{-2} \mathrm{~s}^{-1}$ (Fig. 4A). However, at the $10 \mathrm{~m}$ and $20 \mathrm{~m}$ stations inhibition was observed at irradiances above 141 and $52 \mu \mathrm{mol}$ photons $\mathrm{m}^{-2} \mathrm{~s}^{-1}$, respectively. These in situ data showed an adaptation of the phototrophic community to the gradually decreasing irradiance at increasing water depth (Fig. 4). Increasing the period of actinic light from 10 to $120 \mathrm{~s}$, increased the relative ETR and raised the irradiance at which saturation and inhibition was observed (Fig. 4). However, the light curve measured after $120 \mathrm{~s}$ of actinic light did not represent steady state and measurements per- 
formed after 10, 120 and $180 \mathrm{~s}$ of actinic light demonstrated a transient adaptation during all 3 min (data not shown). Repetition of the RLC after 10 min at in situ irradiance showed that the phototrophic community had reversed to the original state. Thus, the photosynthesis of benthic diatoms acclimated reversibly to changes in irradiance within minutes. Rapid light curves measured in pre-incubated sediment cores in the laboratory were very similar to each other irrespective of the water depth from which they were recovered (Fig. 4). The communities were, however, still able to change their photosynthetic performance within a few minutes after changes in irradiance
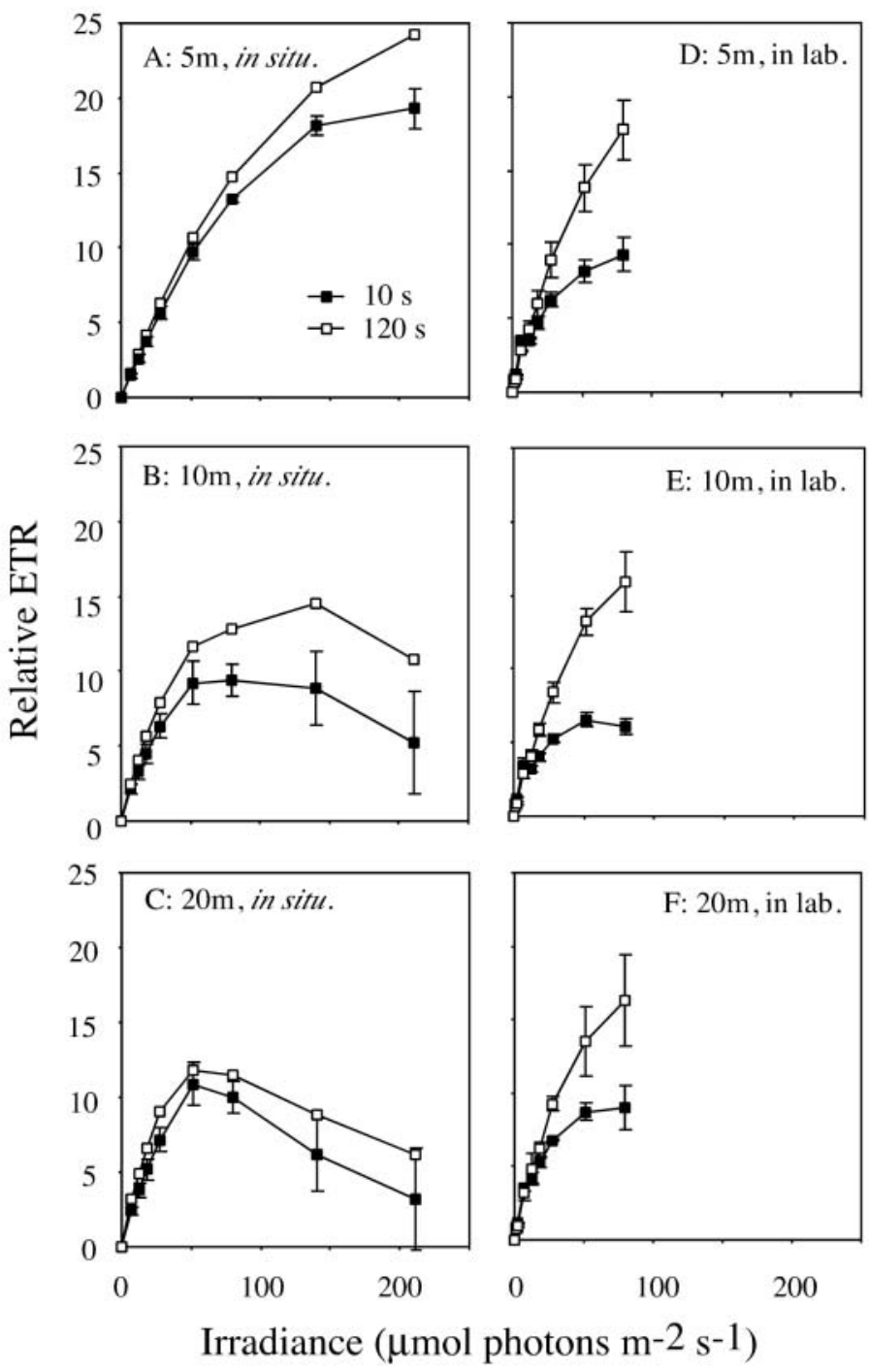

Fig. 4. Relative PSII related electron transport rate (ETR) as a function of irradiance as measured in situ and in recovered sediment cores. (ם) Measurements obtained after $10 \mathrm{~s}$ of actinic light; $(\square)$ measurements performed after $120 \mathrm{~s}$ (mean \pm $\mathrm{SD} ; \mathrm{n}=3)$; no 120 s replicates were performed in situ
(Fig. 4). For the $30 \mathrm{~m}$ station, no in situ measurements were performed, but the laboratory data were similar to the laboratory measurements performed at the 3 shallow stations (data not shown). We measured no activity at the $40 \mathrm{~m}$ station and $F$-values were generally low.

The $F_{0}$-values measured in recovered sediment cores were directly correlated with the average chl a concentration of the upper $3 \mathrm{~mm}$ to a chl a concentration of $40 \mathrm{\mu g} \mathrm{g}^{-1}$ (Fig. 5), which is in accordance with previous measurements made for intertidal microalgae (Barranguet \& Kromkamp 2000). To access the spatial scale of variability of benthic diatom biomass, F-values were measured in situ along the10 $\mathrm{m}$ isobath (Fig. 6A). Data were divided in 9 classes of distance between individual measurements: $0-0.025,0.025-0.25,0.25-1,1-2,2-5,5-8$, $8-50,50-150,150-1000$ and $>1000 \mathrm{~m}$. The spatial autocorrelation estimated as Moran I coefficients (Moran 1950, Legendre \& Legendre 1998) were calculated for all size classes. Positive values and negative values indicated positive and negative autocorrelation, respectively. The correlogram (Fig. 6B) showed a change in sign between the distances classes of 2 to 5 and 5 to $8 \mathrm{~m}$. The biomass of benthic diatoms therefore varied in patches with a lateral distance of 5 to $8 \mathrm{~m}$.

\section{$\mathrm{O}_{2}$ microprofile data}

The coarse sediment at the $5 \mathrm{~m}$ station prevented measurements of reliable $\mathrm{O}_{2}$ microprofiles. However,

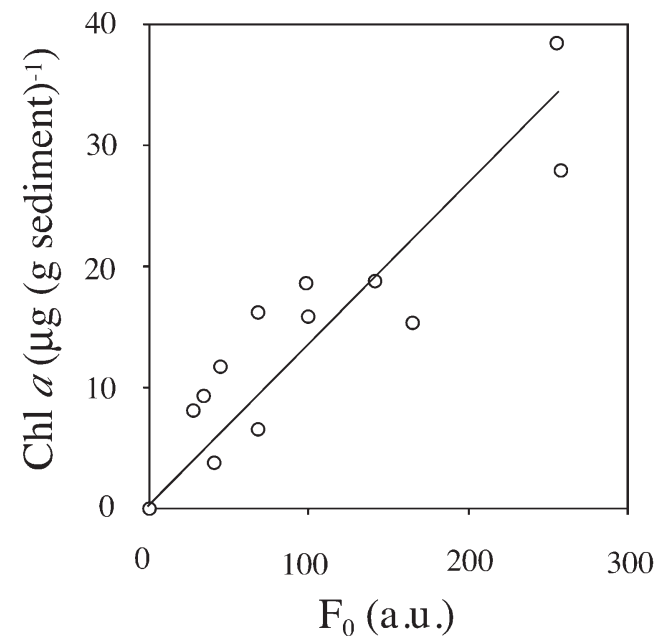

Fig. 5. Minimal fluorescence yield $\left(F_{0}\right)$ as a function of chl a content of the upper sediment layer in recovered sediment cores; linear curve fit through $(0,0)\left(\left[\begin{array}{ccl}\mathrm{chl} & a\end{array}\right]=F_{0} 0.133\right.$; $\left.\mathrm{R}^{2}=0.81\right)$ (a.u. = arbitrary unit) 
for the 3 intermediary stations $(10,20$ and $30 \mathrm{~m})$ the $\mathrm{O}_{2}$ concentration of the diatom covered sediment increased to more than 2 times air-saturation at an irradiance of $80 \mu \mathrm{mol}$ photons $\mathrm{m}^{-2} \mathrm{~d}^{-1}$ (Fig. 7A). In contrast, the $\mathrm{O}_{2}$ concentration at the $40 \mathrm{~m}$ station was independent of the irradiance (not shown). $\mathrm{O}_{2}$ microprofiles measured in cores from 10, 20 and $30 \mathrm{~m}$ after pre-incubation at a given irradiance appeared to be very similar irrespective of the recovery depth. The diffusive $\mathrm{O}_{2}$ exchange (DOE) calculated for the photic zone kept increasing with the irradiance and no inhibition was observed. By compiling all 46 laboratory microprofiles, a PE relationship for the 10, 20 and $30 \mathrm{~m}$ stations was established (Fig. 7B). The compensation irradiance for the photic zone was $4.5 \mu \mathrm{mol}$ photons $\mathrm{m}^{-2} \mathrm{~d}^{-1}$, while the photosynthetic capacity $\left(\mathrm{P}_{\max }\right)$ for the photic zone was $85 \mathrm{mmol}_{2}$ $\mathrm{m}^{-2} \mathrm{~d}^{-1}$ (Fig. 7B). The irradiance at onset of saturation $\left(\mathrm{P}_{\max } / \alpha\right)$ was $32.9 \mu \mathrm{mol}$ photons $\mathrm{m}^{-2} \mathrm{~d}^{-1}$ (Fig. 7B). The few successfully obtained in situ microprofiles followed the trend of the laboratory measurements (Fig. 7B).
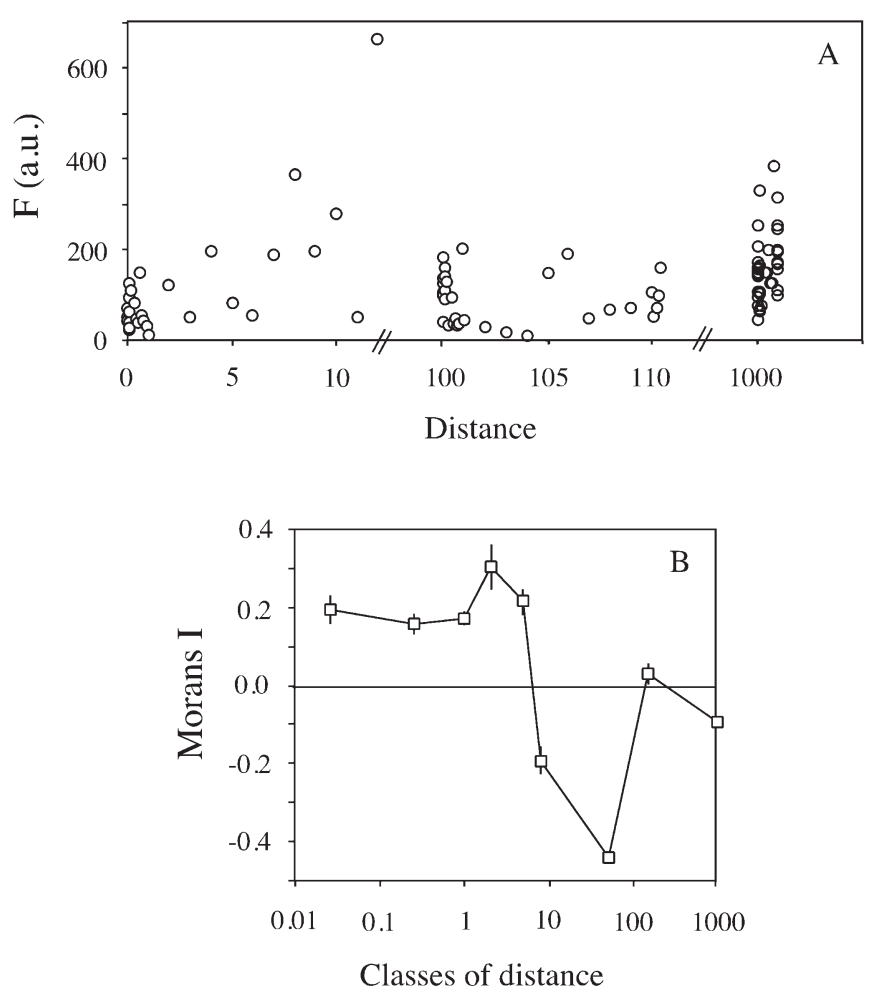

Fig. 6. (A) Fluorescence yield (F) (in arbitrary units) measured along the $10 \mathrm{~m}$ isobath at Daneborg. Ambient irradiance varied between 7 to $10 \mu \mathrm{mol}$ photons $\mathrm{m}^{-2} \mathrm{~s}^{-1}$. (B) A correlogram presenting Morans I coefficients as a function of the classes of distance. Vertical bars indicate the SD of the autocorrelation

\section{Total $\mathrm{O}_{2}$ and DIC exchange rates}

Benthic exchange rates measured by whole core incubations represent the combined activity of sediment, diatoms, meio- and macrofauna. At the 5, 10, 20 and $30 \mathrm{~m}$ stations, the total benthic exchange rates of $\mathrm{O}_{2}$ and DIC showed a linear light dependence, while the rate at the $40 \mathrm{~m}$ station was independent of light (Fig. 8). The total $\mathrm{O}_{2}$ uptake and the DIC release rate in darkness decreased with increasing water depth. The
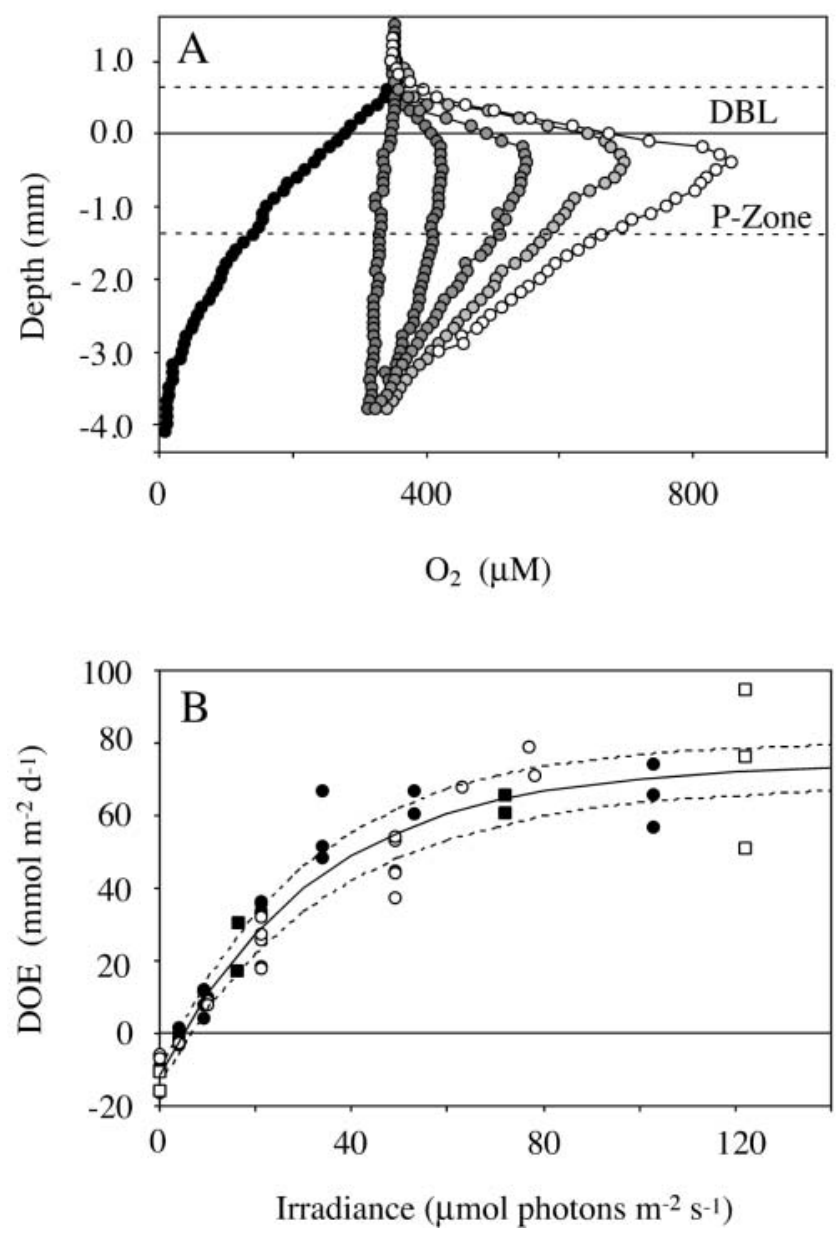

Fig. 7. (A) Six microprofiles measured in diatom covered sediment recovered from the $20 \mathrm{~m}$ station. Measurements were performed at different spots under increasing incident irradiance $\left(0,4,9,21,53,103 \mu \mathrm{mol}\right.$ photons $\left.\mathrm{m}^{-2} \mathrm{~s}^{-1}\right)$. The horizontal line indicates the position of the sediment surface, while broken lines represent the diffusive boundary layer (DBL) and the photic zone (P-Zone), respectively. (B) Diffusive $\mathrm{O}_{2}$ exchange as a function of the incident irradiance. Measurements are from $10(\mathbf{O}), 20(\mathbf{0}), 30(\square)$ and in situ $10 \mathrm{~m}(\mathbf{\square})$. The solid line represents the fitted function $\mathrm{P}=\mathrm{P}_{\max }$ $\left[1-\left(\exp \left(-\alpha E / P_{\max }\right)\right]+R\right.$ (Platt et al. 1980) $\left(R^{2}=0.93\right)$, while dotted lines represent the $95 \%$ confidence interval. Photosynthetic parameters were calcu-lated from the fitted curve as: $\mathrm{P}_{\max }=85.7, \alpha=2.61, \mathrm{R}=-10.96$ 

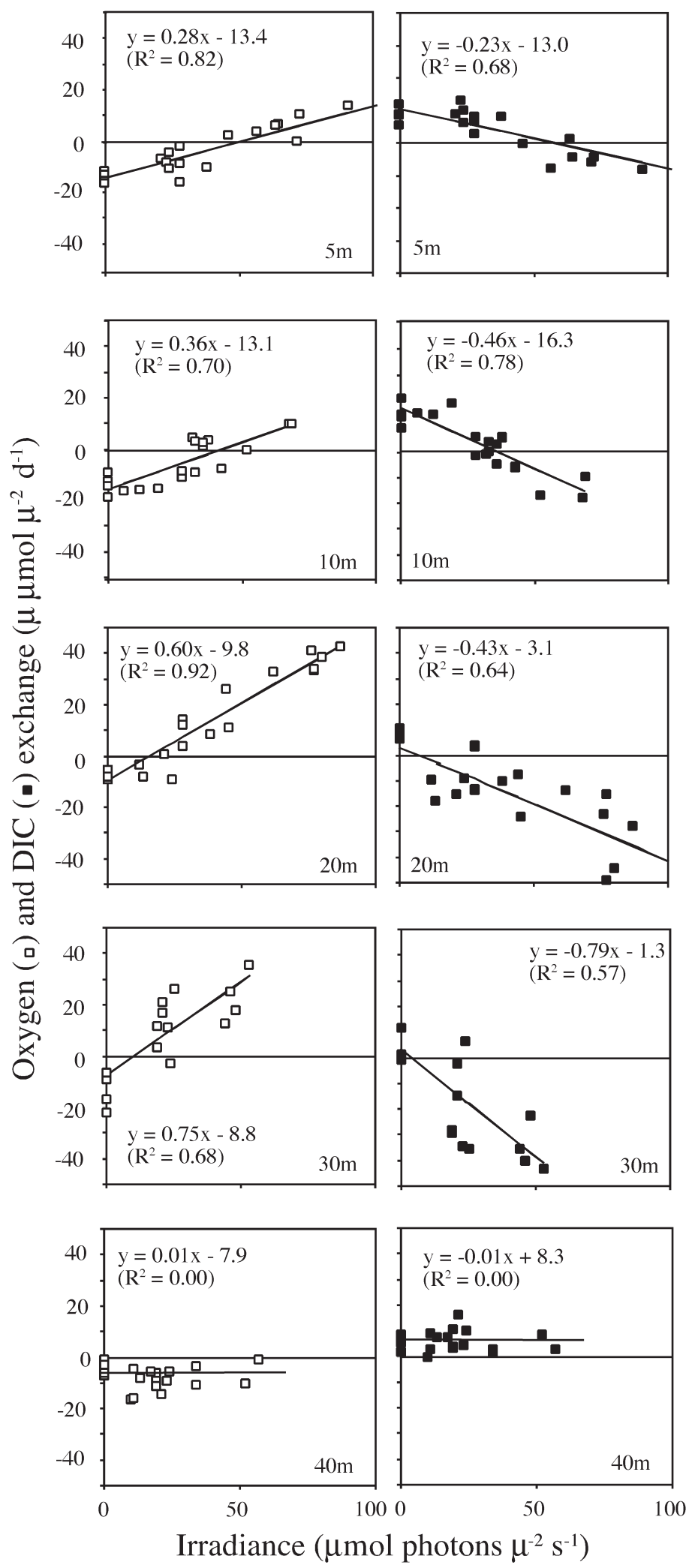

Fig. 8. Total $\mathrm{O}_{2}(\boldsymbol{\square})$ and DIC (ם) exchange rates across the sediment-water interface as a function of incident irradiance for the respective stations. The best linear fit for each data set is included maximal $\mathrm{O}_{2}$ release and DIC uptake in light was observed at the 20 and $30 \mathrm{~m}$ stations (Fig. 8). The irradiance where the benthic community as a whole became net autotrophic decreased with increasing water depth (Fig. 8). The compensation irradiance derived from the TOE data equaled 48, 39, 17 and $12 \mu \mathrm{mol}$ photons $\mathrm{m}^{-2} \mathrm{~s}^{-1}$ for the $5,10,20$ and $30 \mathrm{~m}$ stations, respectively. Similar values were obtained using the DIC exchange rate as a measure for the photosynthetic activity (Fig. 8). The pattern correlated with an increase in the benthic diatom cover (Table 2) and a decrease in macrofauna biomass with increasing water depth (Glud et al. 2000, Sejr et al. 2000). The DIC release rate (and TOE) in darkness increased linearly with the macrofauna biomass (Fig. 9). Changes in the DIC exchange were mirrored in changes of the TOE (Fig. 8) and when the DIC exchange was plotted as a function of TOE data distributed evenly around the $X=$ $Y$ line (Fig. 10). The respiratory coefficient (RQ) for cores without photosynthetic activity (dark incubations and cores recovered from $40 \mathrm{~m}$ ) equaled $1.25 \pm 0.45$. For the light incubated cores, the photosynthetic ratio (PQ) varied significantly but was not different from 1.20 .

\section{DISCUSSION}

\section{Measuring primary production of benthic microphytes}

The primary production of benthic microalgae has mostly been estimated from ${ }^{14} \mathrm{C}$-incubations or $\mathrm{O}_{2}$

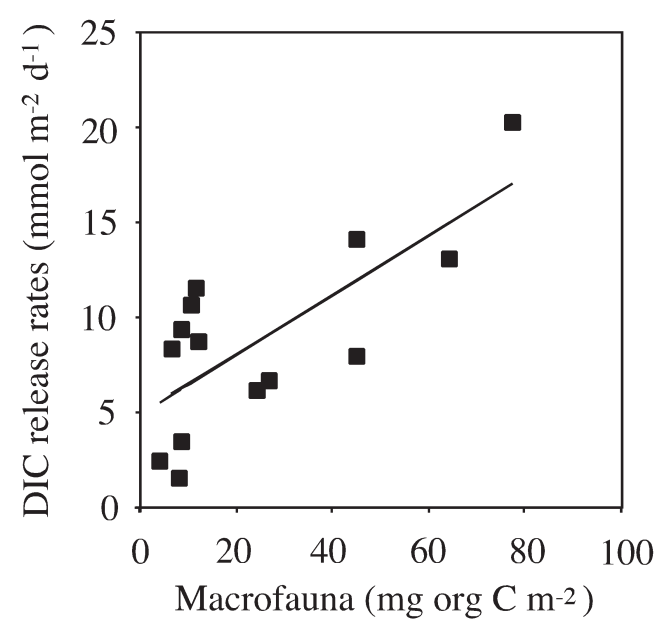

Fig. 9. DIC release rates measured in darkness for cores recovered at water depths $>5 \mathrm{~m}$ as a function of the macrofauna density; fauna samples from the $5 \mathrm{~m}$ station were lost. The solid line shows the best linear curve fit $(y=0.13 x+4.93$; $\left.\mathrm{R}^{2}=0.55\right)$ 
exchange measurements (Cahoon 1999). All of these techniques have their strengths and limitations, and they have been intercalibrated in a range of benthic environments with somewhat conflicting results (e.g. Hunding \& Hargrave 1973, Revsbech et al. 1981, Barranguet et al. 1998). It is beyond the scope of the present study to discuss the pros and cons of these techniques; however, to quantitatively compare produc- tivity it is essential to clearly define what is understood by primary production. The ${ }^{14} \mathrm{C}$-incubation technique measures the gross photosynthetic rate (depending on the incubation period), while the $\mathrm{O}_{2}$ exchange approach measures the net photosynthetic rate.

Benthic phototrophic communities are characterized by a tight spatial and temporal coupling between production and consumption of organic $\mathrm{C}$ (Epping \& Jørgensen 1996, Kühl et al. 1996, Glud et al. 1999, Fenchel \& Glud 2000). Photosynthetic and heterotrophic microbes are oriented in a mosaic structure, where active phototrophs leak $\mathrm{O}_{2}$ and organic $\mathrm{C}$ to the surrounding heterotrophs, which in return lower the oxygenic stress on the community and deliver DIC for photosynthesis (Glud et al. 1992, Kühl et al. 1996). Consequently, the respiratory processes in the community are light dependent (e.g. Epping \& Jørgensen 1996). Additionally, there is a tight coupling between the activities in the deeper aphotic sediment strata and the phototrophic community in the sediment surface layer. $\mathrm{O}_{2}$ produced at the surface during illumination, helps to repay the $\mathrm{O}_{2}$ debt from anaerobic degradation, while DIC (and

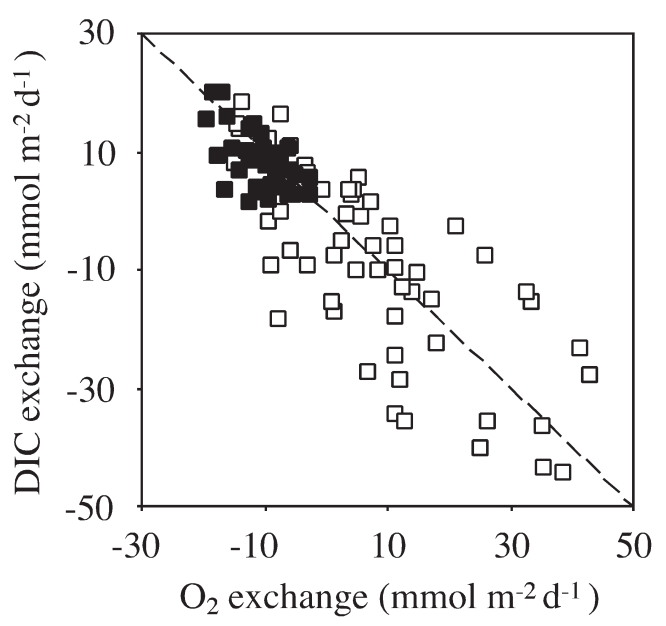

Fig. 10. DIC exchange rate as a function of the $\mathrm{O}_{2}$ exchange rate for all core incubations. (प) Measurements on sediment with diatoms in light; (ם) measurements performed in darkness or with cores without any diatom cover (40 m station). The dashed line shows the relation $x=y$ nutrients) are supplied from the aerobic and the anaerobic mineralization processes, thereby the $\mathrm{O}_{2}$ penetration depth typically increases during the day and this affects the $\mathrm{O}_{2}$ and DIC exchange at the surface (Rysgaard et al. 1995, Epping \& Jørgensen 1996, Fenchel \& Glud 2000). This dynamic can be resolved by use of microsensor techniques, and in the present work we have used $\mathrm{O}_{2}$ microsensors to quantify the net release rate of $\mathrm{O}_{2}$ from the phototrophic community (Fig. 7), and defined this as net photosynthesis. This rate is obviously lower than the gross photosynthetic rate, which can be resolved by the so-called light-dark shift microsensor technique (or by the ${ }^{14} \mathrm{C}$ incubation technique) (Revsbech \& Jørgensen 1983, Glud et al. 1992, Lassen et al. 1998). However, for studies in heterogeneous ecosystems this technique is too elaborate. A few simultaneous microsensor determinations of net and gross photosynthesis performed in an irradiance interval of 31 to $200 \mu \mathrm{mol}$ photons $\mathrm{m}^{-2} \mathrm{~s}^{-1}$ in the laboratory revealed that $83 \pm 4 \%(\mathrm{n}=5)$ of $\mathrm{O}_{2}$ produced during the gross photosynthesis was consumed within the photic zone. This is at the higher end of previously presented rates for various phototrophic communities (Canfield \& Des Marais 1993, Kühl et al. 1996, Glud et al. 1999, Fenchel \& Glud 2000).

PAM flourometry represents a fast and simple approach for estimating the biomass and the photosynthetic activity of benthic microalgae (Barranguet \& Kromkamp 2000, Kühl et al. 2001). However, to transform the data into more quantitative measures like $\mathrm{O}_{2}$ production, DIC fixation or chl a concentration, an inter-calibration with the traditional approaches is required. Our relative ETR rates determined in the laboratory correlated well to the DOE and confirmed that robust empirical relations can be established for a given environment (Fig. 11). Both techniques revealed a depth independent photosynthetic activity for communities adapted to a given irradiance. This validates the use of a single PE relation for extrapolation of the total productivity of diatom-covered sediments of Young Sound. Measurements of the relative ETR after variable exposure to irradiance demonstrated that benthic diatoms quickly optimize their photosynthetic apparatus to changed light conditions. Similar observations for both micro- and macroalgae under ice cover were made recently (Kühl et al. 2001); however, the mechanism behind this fast acclimation is unclear and needs further investigation.

Total exchange rates quantify the net photosynthesis of the integrated benthic community. The integral respiration activity of fauna and non-photosynthetic microbes counteracts the photosynthetic $\mathrm{O}_{2}$ production within the photic zone, and the integrated net photo- 
synthesis will be lower than for the DOE outlined above. The $\mathrm{O}_{2} /$ DIC exchange ratio in light exposed cores was not significantly different from the generally accepted photosynthetic quotient (PQ) of 1.20 (Strickland \& Parsons 1972); consequently we have used this value in the calculations below.

\section{Spatial and temporal variation in the benthic microphyte distribution}

The distribution of benthic diatoms was very patchy and chl a concentration (as calculated from measured $F$-values using the relation in Fig. 5) varied by a factor of 60 . The mean value was $125 \pm 96$ (SD) and all values were within the detection limit. This indicates that the areas recognized as bare sediment (Fig. 3, Table 2) contained active phototrophs. The distinct depth related pattern of diatom coverage resolved in Table 2 only accounts for the visually encountered diatom mats. However, the exchange rates resolved by whole core incubation and a few microsensor measurements performed in illuminated bare sediment (data not shown) confirmed that the diatom mats were the quantitatively most important component of the microbenthic photosynthesis (Fig. 8). Statistical analysis of the spatial autocorrelation showed that the diatom cover at $10 \mathrm{~m}$ water depth varied on a spatial scale of 5 to $8 \mathrm{~m}$ (based on 96 measurements). The bivalves at 5 to $15 \mathrm{~m}$ water depths in the investigated area off Daneborg serve as a food source for a local walrus colony (Born et al. 1997). It can be speculated that the disturbance due to walrus feeding affected the observed patchiness of benthic microalgae.

Numerous investigations especially in intertidal areas have demonstrated vertical migration of benthic diatoms as a function of irradiance or tides (Heckman 1985, Pinckney \& Zingmark 1991). For the range of irradiances applied in the laboratory, no migratory activity was observed. However, the dominant genera were motile and exposing the phototropic community to very high light levels induced a phobic downward migration. This was observed both with microelectrodes and PAM measurements (data not shown). We cannot exclude in situ migration, but divers observed no such activity and migration is not accounted for in the calculations below.

\section{Importance of benthic diatoms for primary production in Young Sound}

From the measured in situ irradiance, extinction coefficients and the PE relation for the DOE, an average net photosynthesis of the diatom-covered sedi- ment at different water depths could be calculated (Table 3). By only accounting for the periods of positive net photosynthesis (irradiance $>4.5 \mu \mathrm{mol}$ photons $\mathrm{m}^{-2}$ $\mathrm{s}^{-1}$ ), a maximum net production of $420 \mathrm{mgC} \mathrm{m}^{-2} \mathrm{~d}^{-1}$ was obtained for the $5 \mathrm{~m}$ station in July. The rate decreased with the light availability and reached a minimum of $70 \mathrm{mg} \mathrm{C} \mathrm{m}^{-2} \mathrm{~d}^{-1}$ in September at the $30 \mathrm{~m}$ station (Table 3). Integrated over the open water period, the net photosynthesis in the diatom covered patches equaled $32,30,14$ and $9 \mathrm{~g} \mathrm{C} \mathrm{m}^{-2}$ for the 5, 10, 20 and $30 \mathrm{~m}$ stations, respectively (Table 3 ).

During periods with an incident irradiance below the compensation point, the photic zone was netheterotrophic and the 'dark-respiration' during these periods accounted for 7 to $88 \%$ of the net photosynthesis measured at 'day-time' (Table 3). Based on a diel calculation, the net photosynthesis therefore only accounted to $20,19,5$ and $2 \mathrm{gC} \mathrm{m}^{-2}$ for the 5,10,20 and $30 \mathrm{~m}$ stations, respectively. These measures only integrate the activity of the diatom covered areas (Table 3). The whole core incubation also included the activity in areas without diatoms and the fauna mediated $\mathrm{O}_{2}$ uptake, and for these measurements, the light compensation point was significantly higher. However, the photosynthesis of benthic diatoms actually balanced the $\mathrm{C}$ requirement of the integrated seafloor (including bare sediment and fauna activity) at the 5 and $10 \mathrm{~m}$ stations during July. During the rest of the period the entire benthic community was net heterotrophic integrated on a diel scale (not shown).

Our daily net photosynthetic rates are intermediate to the few previous estimates on benthic primary productivity performed at water depths >5 m (Cahoon 1999). To our knowledge, only 2 other studies have

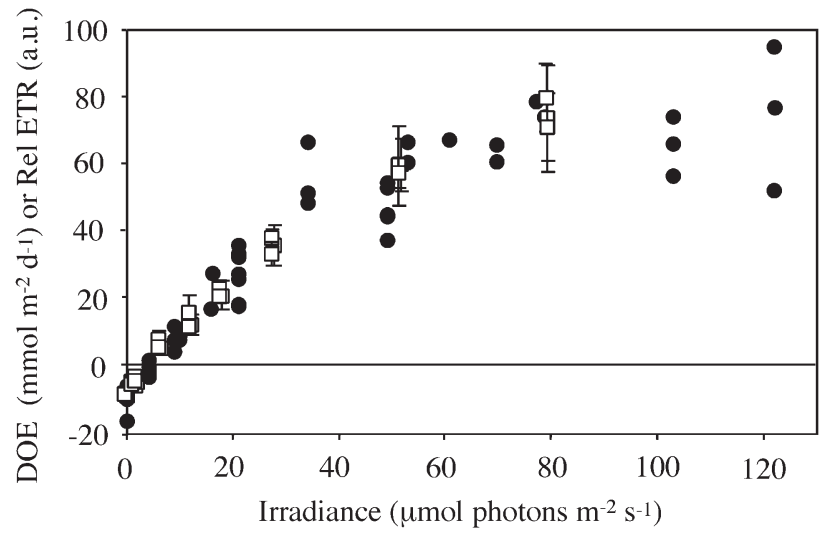

Fig. 11. Diffusive $\mathrm{O}_{2}$ uptake $(\bullet)$ and the relative electron transport rate (Rel ETR) ( $\square$, arbitrary units) of diatom covered sediment as a function of the irradiance. Data are extracted from Figs. 4D,E,F \& 7B. The original ETR were linearly converted using the equation $y=5 x-9$ in order to use one axis (a.u. = arbitrary unit) 
Table 3. Production estimates for benthic diatoms in outer Young Sound (YS) in 2000, (40 m excluded since no activity was observed at this station). 'Light' columns only include periods with positive net-photosynthesis, while 'diel' columns integrate the complete period. -: Negative values

\begin{tabular}{|c|c|c|c|c|c|c|c|c|}
\hline \multirow[t]{2}{*}{ Net photosynthesis } & \multicolumn{2}{|c|}{5 m station } & \multicolumn{2}{|c|}{10 m station } & \multicolumn{2}{|c|}{20 m station } & \multicolumn{2}{|c|}{$30 \mathrm{~m}$ station } \\
\hline & Light & Diel & Light & Diel & Light & Diel & Light & Diel \\
\hline Jul $\left(\mathrm{mgC} \mathrm{m}^{-2} \mathrm{~d}^{-1}\right)^{\mathrm{a}}$ & 420 & 390 & 407 & 362 & 221 & 131 & 147 & 58 \\
\hline $\operatorname{Aug}\left(\mathrm{mgC} \mathrm{m}^{-2} \mathrm{~d}^{-1}\right)$ & 412 & 288 & 397 & 263 & 198 & 72 & 123 & 15 \\
\hline $\operatorname{Sep}\left(m g C m^{-2} d^{-1}\right)$ & 340 & 127 & 315 & 108 & 122 & - & 70 & - \\
\hline Total $\left(\mathrm{gC} \mathrm{m}^{-2}\right.$ season $\left.^{-1}\right)$ & 31.5 & 20.4 & 30.0 & 18.8 & 14.2 & 4.9 & 8.9 & 1.7 \\
\hline
\end{tabular}

Table 4. Contributions of different primary producers to the total production in Young Sound, NE Greenland

\begin{tabular}{|c|c|c|c|c|c|}
\hline Community & $\begin{array}{l}\text { Depth } \\
(\mathrm{m})\end{array}$ & $\begin{array}{l}\text { Average activity } \\
\left(\mathrm{mgC} \mathrm{m}^{-2} \mathrm{~d}^{-1}\right)\end{array}$ & $\begin{array}{l}\text { Length of season } \\
\text { (d) }\end{array}$ & $\begin{array}{l}\text { Covered area }{ }^{\mathrm{a}} \\
\quad\left(\mathrm{km}^{2}\right)\end{array}$ & $\begin{array}{l}\text { Primary production } \\
\text { (tC in Young Sound) }\end{array}$ \\
\hline \multirow[t]{5}{*}{ Benthic diatoms } & 5 & 387 & 80 & 3.5 & 108 \\
\hline & 10 & 367 & 80 & 3.5 & 103 \\
\hline & 20 & 172 & 80 & 5.8 & 80 \\
\hline & 30 & 109 & 80 & 2.3 & 20 \\
\hline & Total & & & & $311(16 \%)$ \\
\hline \multirow[t]{4}{*}{ Coralline red algae } & 20 & 200 & 80 & 0.1 & 1.6 \\
\hline & 30 & 154 & 80 & 0.5 & 6.2 \\
\hline & 40 & 108 & 80 & 0.1 & 0.9 \\
\hline & Total & & & & $8.7(0.8 \%)$ \\
\hline \multirow{2}{*}{\multicolumn{2}{|c|}{ Laminaria saccharina }} & $28.9^{\mathrm{b}}$ & 80 & 19.5 & $43(2 \%)$ \\
\hline & & & & & 390 (21\%) \\
\hline \multicolumn{2}{|l|}{ Ice lgae $^{c}$} & 0.04 & 60 & 131.8 & $0.3(0.0 \%)$ \\
\hline \multirow[t]{2}{*}{ Phytoplankton ${ }^{c}$} & & 103 & 100 & $111.0^{\mathrm{d}}$ & $1143(60 \%)$ \\
\hline & Total & & & & $1896(100 \%)$ \\
\hline \multicolumn{6}{|c|}{ accounting for the coverage of the respective phototrophic communities } \\
\hline \multirow{2}{*}{\multicolumn{6}{|c|}{${ }^{\mathrm{b}}$ The activity is per seafloor area and not community area as for the other phototrophic communities }} \\
\hline & & & & & \\
\hline \multicolumn{6}{|c|}{${ }^{\mathrm{d}}$ Corrected for an estimated photic zone depth of $30 \mathrm{~m}$ (Rysgaard et al. 1999) } \\
\hline
\end{tabular}

presented production estimates for benthic microalgae in the Arctic (Matheke \& Horner 1974, Horner \& Schrader 1982). These studies applied the ${ }^{14} \mathrm{C}$-incubation technique during a seasonal study off Alaska at 5 and $7 \mathrm{~m}$ of water depth, respectively. In the Beaufort Sea the contribution of benthic microalgae was negligible, while it ranged between 1.9 and $57 \mathrm{mgC} \mathrm{m}^{-2} \mathrm{~h}^{-1}$ during the ice-free period and represented the most important contribution to the primary production in the Chukchi Sea (near Barrow) (Matheke \& Horner 1974, Horner \& Schrader 1982). It is very difficult to compare these gross rates to our production estimates since no information on irradiance or area cover was supplied. However, by using the approach of Cahoon (1999), the primary production of benthic microalgae in the Chukchi Sea was estimated to $16 \mathrm{~g} \mathrm{C} \mathrm{m}^{-2} \mathrm{yr}^{-1}$. This is intermediate to the net photosynthesis resolved along the depth transect of the present study. Our data underline the potential importance of benhic microalgae for aquatic primary production in shallow Arctic areas.

On the assumption that the investigated transect is representative for the outer Young Sound, we used our production data to extrapolate the production within the entire area knowing the coverage of benthic diatoms (Table 2) and the bathymetry (Glud et al. 2000). The assumption of abundant sediment cover of benthic diatoms is partly verified by the PAM measurements performed along the $10 \mathrm{~m}$ isobath (Fig. 6) and by extensive video recordings of the seafloor in the area. When only accounting for the periods with an irradiance $>4.5 \mu \mathrm{mol}$ photons $\mathrm{m}^{-2} \mathrm{~d}^{-1}$, the total net photosynthesis of benthic diatoms equaled $311 \mathrm{tC}$ season $^{-1}$ (Table 4). Robust PE relations between net photosynthesis and incident irradiance for the dominant crustose coralline red algae (Phymatolithon tenue and 
Phymatolithon foecundum) and the brown algae Laminaria saccharina have been presented (Borum et al. 2002, Roberts et al. 2002). By using the estimated coverage and the biomass from these original publications and our light data, it was estimated that the crustose red algae and Laminaria account for a net photosynthesis of 8.7 and $43 \mathrm{tC}$ season $^{-1}$, respectively (Table 4). However, these 2 groups only account for $\sim 10 \%$ of the macroalgal biomass in the Sound, the remaining fraction being dominated by Desmarestia aculeate and Fucus evanescens (Borum et al. 2002). A rough estimate on their contribution can be made assuming that these 2 algae have the same photosynthetic characteristics and the same depth distribution as Laminaria saccharina (Table 4). The complete benthic primary production of Young Sound during the ice-free period thereby reaches approximately $750 \mathrm{t} \mathrm{season}^{-1}$ (Table 4). This activity mainly occurs at water depths $<30 \mathrm{~m}$ (ignoring a minor contribution from crustose coralline algae at $40 \mathrm{~m}$ ) and the average activity of benthic photosynthesis in this depth range during the entire season thus equaled $261 \mathrm{mg} \mathrm{C} \mathrm{m}^{-2} \mathrm{~d}^{-1}$.

Seasonal studies on the gross primary production of the phytoplankton and the ice algal communities have also been conducted in Young Sound by use of the ${ }^{14} \mathrm{C}$ incubation technique (Rysgaard et al. 1999, 2001). The productivity of ice algae was very low, presumably due to extensive snow cover and high freshwater inputs to the area in the early spring (Rysgaard et al. 2001). Extrapolated to the area of Young Sound, the ice algae only accounted for a gross photosynthetic rate of $0.3 \mathrm{tC}$ season $^{-1}$ (Table 4). The total phytoplankton productivity was $\sim 1150$ tC during the season of 1996 . However, for water depths $<30 \mathrm{~m}$ the average activity was only approximately $40 \mathrm{mgC} \mathrm{m}^{-2} \mathrm{~d}^{-1}$, which is equivalent to $15 \%$ of the benthic net photosynthesis.

The benthic heterotrophic community is fuelled by primary production. However, only a minor fraction of the gross pelagic primary production reaches the sediment, due to efficient $\mathrm{C}$ and nutrient recycling in the upper water column (Rysgaard et al. 1999). In contrast, benthic primary production, especially that of microalgae, is closely coupled to the benthic heterotrophic community. For water depths $<30 \mathrm{~m}$, the average benthic net photosynthesis was thus quantitatively more important than the gross photosynthesis of the pelagic community and the benthic primary production at these water depths is a primary food source for the benthic community. In this context, it has to be underlined that we have only estimated the net photosynthesis of the benthic community, while the measurements for the pelagic environment represent gross photosynthesis. We have no good measurements for the autotrophic-heterotrophic coupling in the investigated diatom communities; however, based on the few simultaneous measurements of the gross and net photosynthesis, the gross rates were 5.8 times $( \pm 0.2, \mathrm{n}=5)$ higher than the net rates. Gross primary production estimates for benthic diatoms would be correspondingly higher.

The present study concludes that benthic primary production can be an important $\mathrm{C}$ source for the benthos in shallow Arctic waters. In Young Sound, the benthic primary production was roughly evenly distributed between micro- and macroalgae. Altogether benthic photosynthesis accounted for at least $1 / 3$ of the total aquatic primary production in Young Sound.

Acknowledgements. This study was financially supported by The Danish Natural Science Research Council, The Carlsberg Foundation (Denmark), the Max Planck Society and by the European Union in the form of a TMR stipend (FW: HPMF-CT2000-00569). The Danish Military Division, Sirius, is gratefully acknowledged for their hospitality and help during the study. Additionally, we would like to thank A. Glud and E. Frandsen, for technical assistance. P. B. Christensen and M. Sejr are thanked for help with photo documentation.

\section{LITERATURE CITED}

Barranguet C, Kromkamp J (2000) Estimating primary production rates from photosynthetic electron transport in estuarine microphytobenthos. Mar Ecol Prog Ser 204: 39-52

Barranguet C, Kromkamp J, Peene J (1998) Factors controlling primary production and photosynthetic characteristics of intertidal microphytobenthos. Mar Ecol Prog Ser 173:117-126

Born EV, Dietz R, Jørgensen H, Knutsen LO (1997) Historical and present distribution, abundance and exploitation of Atlantic walruses (Obobenus rosmarus) in Eastern Greenland. Medd Gronl Biosci 46:1-73

Borum J, Pedersen MF, Krause-Jensen D, Christensen PB, Nielsen K (2002) Biomass, photosynthesis and growth of Laminaria saccharina in a high Arctic fjord, NE Greenland. Mar Biol (in press)

Broecker WS, Peng TH (1974) Gas exchange rates between air and sea. Tellus 26:21-35

Cahoon LB (1999) The role of benthic microalgae in neritic ecosystems. Oceanogr Mar Biol Annu Rev 37:47-86

Cahoon LB, Cooke JE (1992) Benthic microalgal production in Onslow Bay, North Carolina, USA. Mar Ecol Prog Ser 84: 185-196

Canfield DE, Des Marais DJ (1993) Biogeochemical cycles of carbon, sulfur and free oxygen in a microbial mat. Geochim Cosmochim Acta 57:3971-3984

Colijn F, de Jonge VN (1984) Primary production of microphytobenthos in the Ems-Dollard estuary. Mar Ecol Prog Ser 14:185-196

Cota GF, Legendre L, Grosselin M, Ingram RG (1991) Ecology of bottom ice algae: I. Environmental controls and variability. J Mar Syst 2:257-277

Crank J (1983) The mathematics of diffusion. Clarendon Press, Oxford

Epping EHG, Jørgensen BB (1996) Light-enhanced oxygen respiration in benthic phototrophic communities. Mar Ecol Prog Ser 139:193-203

Fenchel T, Glud RN (2000) Benthic primary production and 
$\mathrm{O}_{2}-\mathrm{CO}_{2}$ dynamics in a shallow water sediment: spatial and temporal heterogeneity. Ophelia 53:159-171

Glud RN, Ramsing NB, Revsbech NP (1992) Photosynthesis and photosynthesis coupled respiration in natural biofilms quantified with oxygen microelectrodes. J Phycol 28: $51-60$

Glud RN, Holby O, Hoffmann F, Canfield DE (1998) Benthic mineralization and exchange in Arctic sediments (Svalbard, Norway). Mar Ecol Prog Ser 173:237-251

Glud RN, Kühl M, Kohls O, Ramsing NB (1999) Heterogeneity of oxygen production and consumption in a photosynthetic mat. J Phycol 35:270-279

Glud RN, Risgaard-Petersen N, Thamdrup B, Fossing H, Rysgaard S (2000a) Benthic carbon mineralization in a high-arctic sound. Mar Ecol Prog Ser 206:59-71

Glud RN, Gundersen JK, Ramsing NB (2000b) Electrochemi$\mathrm{cal}$ and optical oxygen microsensors for in situ measurements. In: Buffle J, Horvai G (eds) In situ analytical techniques for water and sediment. Wiley-Liss, Chester, p 19-75

Glud RN, Rysgaard S, Kühl M (2002) A laboratory study on $\mathrm{O}_{2}$ dynamics and photosynthesis in ice algal communities: Quantification by microsensors, $\mathrm{O}_{2}$ exchange rates, ${ }^{14} \mathrm{C}$ incubations and a PAM fluorometer. Aquat Microb Ecol 27:301-311

Grebmeier JM, Mcroy CP (1989) Pelagic-benthic coupling on the shelf of northern Bering and Chukchi Seas. III. Benthic food supply and carbon cycling. Mar Ecol Prog Ser 53: $79-91$

Grebmeier JM, Mcroy CP, Feder HM (1988) Pelagic-benthic coupling on the shelf of northern Bering and Chukchi Seas. I. Food supply source and benthic biomass. Mar Ecol Prog Ser 48:57-67

Grøntved J (1960) On the productivity of microbenthos and phytoplankton in some Danish fjords. Medd Dan FiskHavunders 3:1-17

Gundersen JK, Jørgensen BB (1990) Microstructure of diffusive boundary layers and the oxygen uptake of the sea floor. Nature 345:604-607

Heckman CW (1985) The development of vertical migration patterns in the sediments of estuaries as a strategy for algae to resist drift with tidal currents. Int Rev Gesamten Hydrobiol 70:151-164

Hofstraat JW, Peeters JCH, Snel JFH, Geel C (1994) Simple determination of photosynthetic efficiency and photoinhibition of Dunaliella teriolecta by saturation pulse fluorescence measurements. Mar Ecol Prog Ser 103:187-196

Horner R, Schrader GC (1982) Relative contribution of ice algae, phytoplankton, and benthic microalgae to primary production in nearshore regions of the Beaufort Sea. Arctic 35:485-503

Hsiao SIC (1988) Spatial and seasonal variations in primary production of sea ice microalgae and phytoplankton in Frobisher Bay, Arctic Canada. Mar Ecol Prog Ser 44: 275-285

Hulth S, Blackburn TH, Hall POJ (1994) Arctic sediments (Svalbard): Consumption and microdistribution of oxygen. Mar Chem 46:293-316

Hunding C, Hargrave BT (1973) A comparison of benthic microalgal production measured by $\mathrm{C}^{14}$ and oxygen methods. J Fish Res Board Can 30:309-312

Jespersen AM, Christoffersen K (1987) Measurements of chlorophyll a from phytoplankton, using ethanol as extraction solvent. Arch Hydrobiol 109:445-454

Kirk JTO (1994) Light and photosynthesis in aquatic ecosystems, 2nd edn. Cambridge Univ Press, Cambridge

Kostka JE, Thamdrup B, Glud RN, Canfield DE (1999) rates and pathways of carbon oxidation in permanently cold Arctic sediments. Mar Ecol Prog Ser 180:7-21

Kühl M, Glud RN, Ploug H, Ramsing NB (1996) Microenvironmental control of photosynthesis and photosynthesiscoupled respiration in an epilithic cyanobacterial biofilm. J Phycol 32:799-812

Kühl M, Glud RN, Borum J, Roberts R, Rysgaard S (2001) Photosynthetic performance of surface associated algae below sea ice as measured with a pulse amplitude modulated (PAM) fluorometer and $\mathrm{O}_{2}$ microsensors. Mar Ecol Prog Ser 223:1-14

Lassen C, Glud RN, Ramsing NB, Revsbech NP (1998) A method to improve the spatial resolution of photosynthetic rates obtained by oxygen microsensors. J Phycol 34:89-93

Legendre P, Legendre L (1998) Numerical ecology. Developments in environmental modelling, Vol 20, 2nd edn. Elsevier, Amsterdam

Li YH, Gregory S (1974) Diffusion of ions in deep-sea sediments. Geochim Cosmochim Acta 38:703-714

Matheke GEM, Horner R (1974) Primary productivity of the benthic microalgae in the Chucki Sea near Barrow, Alaska. J Fish Res Board Can 31:1779-1786

Middelburg JJ, Barranguet C, Buschker HTS, Herman PMJ, Moens T (2000) The fate of intertidal microphytobenthos carbon: an in situ ${ }^{13} \mathrm{C}$ labeling study. Limnol Oceanogr 45: 1224-1234

Menard H, Smith SM (1966) Hypsometry of ocean basin provinces. J Geophys Res 71:4305-4325

Moran PAP (1959) Notes on continuous stochastic phenomena. Biometrica 37:17-23

Peterson B, Howarth R (1987) Sulfur, carbon and nitrogen isotopes used to trace organic matter flow in the salt-marsh estuaries of Sapelo Island, Georgia. Limnol Oceanogr 32: 1195-1213

Pinckney J, Zingmark RG (1991) Effects of tidal stage and sun angles on intertidal benthic microalgal productivity. Mar Ecol Prog Ser 76:81-89

Piepenburg D, Blackburn TH, von Dorrien CF, Gutt J and 6 others (1995) Partitioning of benthic community respiration in the Arctic (northwestern Barents Sea). Mar Ecol Prog Ser 118:199-213

Platt T, Gallegos CL, Harrison WG (1980) Photoinhibition of photosynthesis in natural assemblages of marine phytoplankton. J Mar Res 38:687-701

Ralph PJ, Gademann R, Larkum AWD, Screiber U (1999) In situ underwater measurements of photosynthetic activity of coral zooxanthellae and other reef dwelling dinoflagellate endosymbionts. Mar Ecol Prog Ser 180:139-147

Rasmussen H, Jørgensen BB (1992) Microelectrode studies of seasonal oxygen uptake in a coastal sediment: role of molecular diffusion. Mar Ecol Prog Ser 81:289-303

Revsbech NP (1989) An oxygen microelectrode with a guard cathode. Limnol Oceanogr 34:474-478

Revsbech NP, Jørgensen BB (1983) Photosynthesis of benthic microflora measured with high spatial resolution by the oxygen microprofile method: capabilities and limitation of the method. Limnol Oceanogr 28:749-756

Revsbech NP, BB Jørgensen (1986) Microelectrodes and their use in microbial ecology. In: Marshall KC (ed) Advances in microbial ecology, Vol 9. Plenum, New York, p 293-352

Revsbech NP, Jørgensen BB, Brix O (1981) Primary production of microalgae in sediments measured by oxygen microprofile, $\mathrm{H}^{14} \mathrm{CO}_{3}{ }^{-}$fixation, and oxygen exchange methods. Limnol Oceanogr 26:717-730

Roberts RD, Glud RN, Kühl M, Rysgaard S (2002) Primary production of crustose coralline red algae in a high Arctic fjord. J Phycol 38:273-283 
Rysgaard S, Christensen PB, Nielsen LP (1995) Seasonal variation in nitrification and denitrification in estuarine sediment colonized by benthic microalgae and bioturbating infauna. Mar Ecol Prog Ser 126:111-121

Rysgaard S, Thamdrup B, Risgaard-Petersen N, Fossing H, Berg P, Bondo PB, Dalsgaard T (1998) Seasonal carbon and nutrient mineralisation in a high-Arctic coastal marine sediment, Young Sound, Northeast Greenland. Mar Ecol Prog Ser 175:261-276

Rysgaard S, Nielsen TG, Hansen BW (1999) Seasonal variation in nutrients, pelagic primary production and grazing in a high-Arctic coastal marine ecosystem, Young Sound, Northeast Greenland. Mar Ecol Prog Ser 179:13-25

Rysgaard S, Kühl M, Glud RN, Hansen JW (2001) Biomass, production and horizontal patchiness of sea ice algae in a high-Arctic fjord (Young Sound, NE Greenland) Mar Ecol Prog Ser 223:15-23

Sambrotto RN, Goering JJ, McRoy CP (1984) Large yearly production of phytoplankton in the western Bering Strait. Science 225:1147-1150

Schreiber U, Gademann R, Ralph PJ, Larkum AWD (1997) Assessment of photosynthetic performance of Prochloron

Editorial responsibility: Otto Kinne (Editor), Oldendorf/Luhe, Germany in Lissoclinum patella in hospite by chlorophyll fluorescence measurements. Plant Cell Physiol 38:945-951

Sejr MK, Jensen KT, Rysgaard S (2000) Macrozoobenthic structure in a high-Arctic East Greenland fjord. Polar Biol 23:792-801

Serodio J, da Silva JM, Cataina F (1997) Nondestructive tracing of migratory rhythms of intertidal benthic microalgae using in vivo chlorophyll a fluorescence. J Phycol 33: $542-553$

Strickland JD, Parson TR (1972) A practical handbook of seawater analysis, 2nd edn. Bull Fish Res B Can 167, 310 pp

Subbarao DV, Platt T (1984) Primary production of Arctic waters. Polar Biol 3:191-201

Sullivan M, Moncreiff C (1990) Edaphic algae are an important component of salt marsh food-webs: evidence from multiple stable isotope analysis. Mar Ecol Prog Ser 62: 149-159

Ullman WJ, Aller RC (1982) Diffusion coefficients in nearshore marine sediments. Limnol Oceanogr 27:552-556

Wenzhöfer F, Holby O, Glud RN, Nielsen HK, Gundersen JK (2000) In situ microsensor studies of a hydrothermal vent at Milos (Greece). Mar Chem 69:43-54

Submitted: January 4, 2002; Accepted: April 4, 2002

Proofs received from author(s): July 26, 2002 